\title{
Glutamine supplementation plans for broilers reared in high-temperature environments
}

\author{
Karina Márcia Ribeiro de Souza Nascimento ${ }^{1 *}$, Charles Kiefer ${ }^{1}$, Juliana Rosa Carrijo Mauad ${ }^{2}$, \\ Luanna Lopes Paiva ${ }^{3}$, Patricia Rodrigues Berno ${ }^{3}$, Danilo Alves Marçal ${ }^{3}$, Henrique Barbosa de \\ Freitas $^{3}$
}

\footnotetext{
${ }^{1}$ Universidade Federal de Mato Grosso do Sul, Faculdade de Medicina Veterinária e Zootecnia, Campo Grande, MS, Brazil.

${ }^{2}$ Universidade Federal da Grande Dourados, Faculdade de Ciências Biológicas e Ambientais, Dourados, MS, Brazil.

${ }^{3}$ Universidade Federal de Mato Grosso do Sul, Programa de Pós-graduação em Ciência Animal, Campo Grande, MS, Brazil.
}

\begin{abstract}
The purpose of this study was to evaluate the effect of glutamine supplementation plans on performance, carcass yield, and cut yield of broilers reared in a high-temperature environment. A fully randomized design was adopted for the experiment, comprising 900 male Hubbard broiler chicks assigned to five treatment groups ( $0 \%$ glutamine from one to 42 days of age; $0.5 \%$ glutamine from 1 to 7 days of age, followed by $0 \%$ from 8 to 42 days; $1.0 \%$ glutamine from 1 to 7 days of age, followed by $0.5 \%$ from 8 to 14 days and $0 \%$ from 15 to 42 days; $1.5 \%$ glutamine from 1 to 7 days of age, followed by $1.0 \%$ from 8 to 14 days, $0.5 \%$ from 15 to 21 days, and $0 \%$ from 22 to 42 days; $2.0 \%$ glutamine from 1 to 7 days of age, followed by $1.5 \%$ from 8 to 14 days, $1.0 \%$ from 15 to 21 days, and $0 \%$ from 22 to 42 days), consisting of six replicates of 30 animals each. The experiment was composed of four periods: pre-starter (1-7 days), starter (8-21 days), grower (22-33 days), and finisher (34-42 days). Glutamine supplementation plans up to 21 days do not improve the performance of broilers in the periods from 1 to 21 and from 1 to 42 days of age reared in a high-temperature environment. Carcass yields and cuts of broilers at 42 days of age are not changed by glutamine supplementation for up to 21 days.
\end{abstract}

Key Words: carcass yield, intestinal structure, performance

\section{Introduction}

Glutamine, a non-essential free amino acid found most abundantly in the bloodstream and intracellular space, is the principal energy substrate for rapidly proliferating cells, such as enterocytes. In situations of stress, glutamine can be decisive for maintenance of intestinal structure and function, being employed by isolated cells of the immune system for lymphocyte proliferation and cytokine production (Newsholme, 2001).

Dietary glutamine supplementation has been previously investigated, revealing beneficial morphological and physiological effects on the gastrointestinal tract of broilers, particularly during early development. However, despite the positive effects of glutamine supplementation on intestinal

Received: May 16, 2016

Accepted: November 29, 2016

*Corresponding author: karina.souza@ufms.br

http://dx.doi.org/10.1590/S1806-92902017000300006

How to cite: Nascimento, K. M. R. S.; Kiefer, C.; Mauad, J. R. C.; Paiva, L. L.; Berno, P. R.; Marçal, D. A. and Freitas, H. B. 2017. Glutamine supplementation plans for broilers reared in high-temperature environments. Revista Brasileira de Zootecnia 46(3):218-222.

Copyright (c) 2017 Sociedade Brasileira de Zootecnia. This is an Open Access article distributed under the terms of the Creative Commons Attribution License (http://creativecommons.org/licenses/by/4.0/), which permits unrestricted use, distribution, and reproduction in any medium, provided the original work is properly cited. quality in poultry, its benefits regarding performance are not consistently evident when birds reach the age of slaughter (Maiorka et al., 2000; Murakami et al., 2007; Zavarize et al., 2011; Martinez et al., 2012).

In addition to nutritional factors, ambient temperature is an important element for successful poultry farming. Birds kept at high ambient temperatures exhibit lower feed intake and weight gain, with negative effects on digestibility and survival rates (Siegel, 1995). Recent studies have shown that glutamine supplementation to the diets of broilers subjected to heat stress alleviates the deleterious effects of high temperature on performance (Dai et al., 2009; Dai et al., 2011).

The purpose of this investigation was to evaluate the effect of glutamine supplementation plans on performance, carcass yield, and cut yield of broilers reared in a hightemperature environment.

\section{Material and Methods}

All procedures used in the present study were approved by the local Animal Care Committee.

The experiment was conducted in Campo Grande, Mato Grosso do Sul, Brazil (latitude 20³0'06.99" S, longitude $54^{\circ} 36^{\prime} 45.52^{\prime \prime} \mathrm{W}$, and $544 \mathrm{~m}$ above sea level). A fully randomized experimental design was adopted, comprising 
900 male Hubbard broiler chicks aged 1 day, assigned to five treatment groups ( $0 \%$ glutamine from 1 to 42 days of age; $0.5 \%$ glutamine from 1 to 7 days of age, followed by $0 \%$ from 8 to 42 days; $1.0 \%$ glutamine from 1 to 7 days of age, followed by $0.5 \%$ from 8 to 14 days and $0 \%$ from 15 to 42 days; $1.5 \%$ glutamine from 1 to 7 days of age, followed by $1.0 \%$ from 8 to 14 days, $0.5 \%$ from 15 to 21 days, and $0 \%$ from 22 to 42 days; $2.0 \%$ glutamine from 1 to 7 days of age, followed by $1.5 \%$ from 8 to 14 days, $1.0 \%$ from 15 to 21 days, and $0 \%$ from 22 to 42 days), consisting of six replicates of 30 animals each.

The experiment comprised four dietary periods: pre-starter (1-7 days), starter (8-21 days), grower (2233 days), and finisher (34-42 days). The experimental isocaloric, isonutrient diets (Table 1) were prepared with corn and soybean meal to meet the nutritional requirements recommended by Rostagno et al. (2011). Glutamine was supplemented by replacing kaolin with a preparation containing 95\% L-glutamine and 5\% glutamic acid $\left(\right.$ Aminogut ${ }^{\circledR}$ ), with total concentrations corresponding to the dietary plans. Feed and water were provided ad libitum throughout the experiment using tubular feeders and automatic bell drinkers.

Temperature was monitored daily at 8.00 and $17.00 \mathrm{~h}$ using a digital maximum-minimum thermometer installed at the center of the shed, in an empty cage located at the same height as the bodies of the animals.

Animals, feed, and leftovers were weighed weekly to determine final body weight, weight gain, feed intake, feed conversion, and production viability corresponding to the age brackets of 1-21 days and 1-42 days.

At 42 days of age, two animals per replicate were removed, the individual weight of which corresponded to the mean weight in the experimental unit within a margin of $\pm 10 \%$. These animals were then fasted, killed by cervical dislocation, exsanguinated, plucked, and eviscerated. Absolute and relative weights of carcass and cuts (breast, thigh + drumstick, wings, back, neck + head, and feet) were measured. Carcass, head + neck, and feet relative weights were based on pre-slaughter weight; breast, thigh + drumstick, wings, and back relative weights were based on carcass weight.

Table 1 - Proximate and nutritional composition of the experimental diets

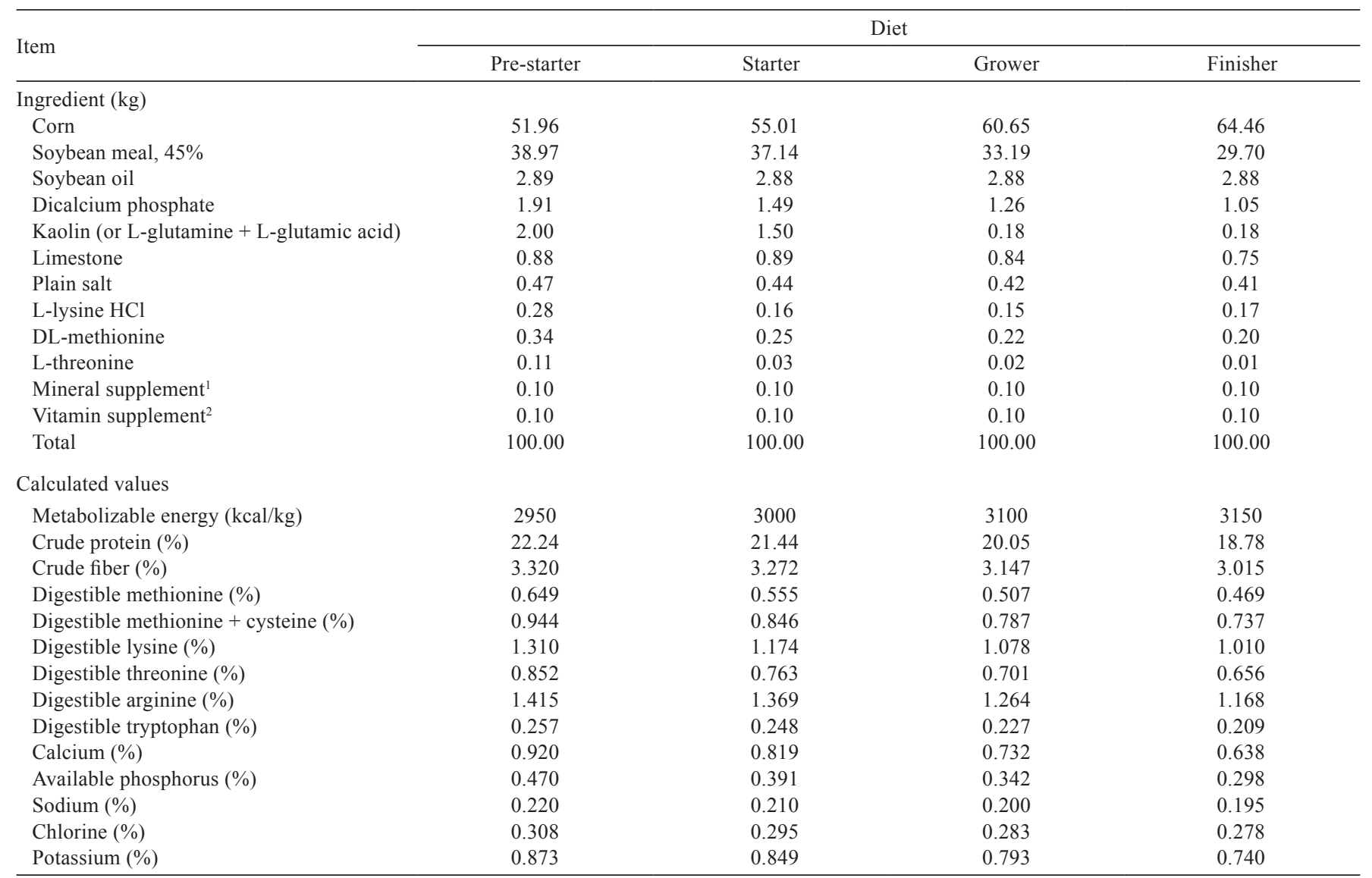

${ }^{1}$ Levels per kg of feed. Mineral supplement: zinc, $11.00 \mathrm{mg}$; pantothenic acid, $3.04 \mathrm{mg}$; iodine, $0.22 \mathrm{mg}$; selenium, $0.06 \mathrm{mg}$; choline, $90 \mathrm{mg}$; iron, $8.48 \mathrm{mg}$; copper, $2.64 \mathrm{mg}$; manganese, $15.15 \mathrm{mg}$.

${ }^{2}$ Levels per kg of feed. Vitamin supplement: vitamin A, $2400 \mathrm{IU}$; vitamin D3, $480 \mathrm{IU}$; vitamin K3, $0.32 \mathrm{mg}$; vitamin B1, $0.51 \mathrm{mg}$; vitamin B2, $1.38 \mathrm{mg}$; vitamin B6, $0.64 \mathrm{mg}$; vitamin B12, $2.88 \mathrm{mg}$; vitamin E, $3.00 \mathrm{mg}$; niacin, $7.12 \mathrm{mg}$. 
Data were subjected to analysis of variance using the PROC GLM program of the SAS package (Statistical Analysis System, University version).

\section{Results and Discussion}

Considering thermal comfort of birds, the maximum temperatures observed were high in all productive periods (Table 2), exceeding the ideal limit recommended by the management guide, being characterized as heat stress condition for broilers, especially in the final production period. The optimal temperature range for broilers is 18-28 ${ }^{\circ} \mathrm{C}$. Above $27{ }^{\circ} \mathrm{C}$, heat production increases in chickens, along with the energy required to maintain body cooling mechanisms, ultimately leading to heat stress (Medeiros et al., 2005).

The glutamine supplementation plans evaluated had no effect $(\mathrm{P}>0.05)$ on the performance of broilers in the period from 1 to 21 days (Table 3). However, performance was lower than that described in the Hubbard management guide: live weight, feed intake, and feed conversion values of $975 \mathrm{~g}, 1257 \mathrm{~g}$, and 1.29, respectively (Hubbard Classic, 2013), results possibly associated with the high ambient temperatures experienced during the experimental period, which may have induced physiological changes, negatively affecting performance.

The performance results observed from 1 to 21 days were consistent with the data reported by Martinez et al. (2012), who found no positive effects of glutamine supplementation on the performance of broilers in this age range. Similarly,

Table 2 - Minimum and maximum temperatures observed during periods

\begin{tabular}{lcccc}
\hline \multirow{2}{*}{ Temperature $\left({ }^{\circ} \mathrm{C}\right)^{1}$} & \multicolumn{4}{c}{ Period } \\
\cline { 2 - 5 } & Pre-starter & Starter & Grower & Finisher \\
\hline Minimum & 30.25 & 29.36 & 27.21 & 29.40 \\
Maximum & 32.38 & 32.75 & 31.71 & 33.03 \\
\hline
\end{tabular}

${ }^{1}$ Obtained temperatures from morning and afternoon average periods.
Maiorka et al. (2000) detected no improvements in the performance of broilers in this age range following supplementation with $1.0 \%$ glutamine. In both studies, however, glutamine supplementation had a beneficial effect on the intestinal mucosa in the first experimental week.

However, positive effects of glutamine on the performance of broilers aged 1 to 21 days have been reported by other investigators. Increased feed intake was observed by Zavarize et al. (2011) upon supplementing 1.0\% glutamine to broilers reared in a thermoneutral environment. Decreased feed intake, increased weight gain, and improved feed conversion were observed by Avellaneda et al. (2008) after supplementing $1.5 \%$ glutamine to broilers aged 1 to 25 days.

In the present study, the absence of glutamine effects on performance may have resulted from the absence of antibiotics or anticoccidials in the experimental diets, considering that broilers, particularly in the early stage of development, are highly susceptible to performanceimpairing pathogens. Linear increases in final weight and weight gain, as well as improved feed conversion, were observed by Sakamoto et al. (2011) upon supplementing $0.5,1.5,3.0$, and $5.0 \%$ glutamine associated with glutamic acid to the diets of broilers from 1 to 21 days of age. However, the vitamin and mineral supplement used in their study contained nicarbazin, an anticoccidial that can promote mineral and amino acid absorption, thus preventing gut epithelial damage by Eimeria.

In the present investigation, glutamine supplementation from 1 to 42 days had no effect $(\mathrm{P}>0.05)$ on performance (Table 4). Akin to the performance results obtained in the experimental period from 1 to 21 days, body weight, feed intake, and feed conversion values were lower than those of $2969 \mathrm{~g}, 5118 \mathrm{~g}$, and 1.72, respectively, described in the Hubbard management guide (Hubbard Classic, 2013). The high temperatures experienced during the experimental period most likely induced lower feed intake, reducing weight gain and worsening feed conversion.

Table 3 - Performance in broilers fed different glutamine supplementation plans from 1 to 21 days of age

\begin{tabular}{|c|c|c|c|c|c|c|c|}
\hline \multirow{2}{*}{ Variable } & \multicolumn{5}{|c|}{ Glutamine supplementation plan ${ }^{1}(\%)$} & \multirow{2}{*}{ P-value } & \multirow{2}{*}{$\mathrm{CV}(\%)$} \\
\hline & $0 ; 0$ & $0.5 ; 0.0$ & $1.0 ; 0.0$ & $1.5 ; 1.0 ; 0.5$ & $2.0 ; 1.5 ; 1.0$ & & \\
\hline Initial weight $(\mathrm{g})$ & 42.28 & 42.23 & 42.04 & 42.09 & 42.21 & 0.9638 & 1.57 \\
\hline Final weight $(\mathrm{g})$ & 610.66 & 641.07 & 648.03 & 618.35 & 670.06 & 0.4696 & 9.18 \\
\hline Weight gain $(\mathrm{g})$ & 568.37 & 598.84 & 606.00 & 576.26 & 627.85 & 0.4702 & 9.84 \\
\hline Feed intake $(\mathrm{g})$ & 825.47 & 857.97 & 910.19 & 828.24 & 928.04 & 0.2309 & 10.44 \\
\hline Feed conversion $(\mathrm{g}: \mathrm{g})$ & 1.46 & 1.43 & 1.50 & 1.44 & 1.50 & 0.9493 & 11.96 \\
\hline Production viability (\%) & 91.112 & 94.445 & 93.334 & 94.666 & 94.000 & 0.8226 & 6.02 \\
\hline
\end{tabular}

${ }^{1}$ Supplementation plans using a preparation containing $95 \%$ L-glutamine and $5 \%$ L-glutamic acid: $(0 ; 0)$ : no glutamine addition; $(0.5 ; 0.0)$ : addition of $0.5 \%$ glutamine from 1 to 7 days of age, followed by $0 \%$ from 8 to 21 days; $(1.0 ; 0.5 ; 0.0)$ : addition of $1.0 \%$ glutamine from 1 to 7 days of age, followed by $0.5 \%$ from 8 to 14 days and $0 \%$ from 15 to 21 days; $(1.5 ; 1.0 ; 0.5)$ : addition of $1.5 \%$ glutamine from 1 to 7 days of age, followed by $1.0 \%$ from 8 to 14 days and $0.5 \%$ from 15 to 21 days; $(2.0 ; 1.5 ; 1.0)$ : addition of $2.0 \%$ glutamine from 1 to 7 days of age, followed by $1.5 \%$ from 8 to 14 days and $1.0 \%$ from 15 to 21 days.

$\mathrm{CV}$ - coefficient of variation. 
In poultry, heat stress can alter intestinal morphology, reducing the capacity to digest and absorb food (Macari et al., 2002), a phenomenon that may have impaired the efficiency of nutrient metabolization in the present study. Evaluating the performance of broilers reared under thermal comfort or heat stress $\left(32^{\circ} \mathrm{C}\right)$, Oliveira et al. (2006) observed decreased feed intake and decreased weight gain at all rearing stages. Dai et al. (2009) reported that, despite supplementing diets with $0.5 \%$ glutamine from 21 to 42 days of age, poultry subjected to heat stress had lower feed intake, lower weight gain, and poorer feed conversion than those experiencing thermal comfort.

The absence of effects of glutamine supplementation on the performance of broilers from 1 to 42 days of age has also been reported in other studies. Sakamoto et al. (2011) found that supplementing glutamine in association with glutamic acid to broilers from 1 to 42 days of age had no effect on weight gain, feed intake, or feed conversion. Zavarize et al. (2011) found no effects of supplementation on performance in the period from 1 to 42 days. Nonetheless, both studies detected beneficial effects of glutamine on performance in the early stages of rearing.

In addition, in a study conducted by Dai et al. (2011), continuous glutamine supplementation from 1 to 42 days of age improved performance in broilers subjected to heat stress.

In the present study, glutamine supplementation had no effect $(\mathrm{P}>0.05)$ on production viability for any of the periods evaluated in contrast with a study by Sakamoto et al. (2011), who reported a quadratic effect of supplementation with glutamine associated with glutamic acid on productive efficiency, which rose by up to $2.8 \%$ with supplementation. In the present study, despite the absence of significant differences, production viability values were relatively low, probably because no antibiotics or anticoccidials were added to the diets in the early stages. The high coefficients of variation obtained reflected high mortality rates.

Glutamine supplementation did not affect $(\mathrm{P}>0.05)$ carcass or cut yields (Table 5). These results are consistent with those obtained by Mussini et al. (2012), who found

Table 4 - Performance of broilers fed different glutamine supplementation plans from 1 to 42 days of age

\begin{tabular}{|c|c|c|c|c|c|c|c|}
\hline \multirow{2}{*}{ Variable } & \multicolumn{5}{|c|}{ Glutamine supplementation plan ${ }^{1}(\%)$} & \multirow{2}{*}{ P-value } & \multirow{2}{*}{ CV $(\%)$} \\
\hline & $0 ; 0$ & $0.5 ; 0.0$ & $1.0 ; 0.5 ; 0.0$ & $1.5 ; 1.0 ; 0.5 ; 0.0$ & $2.0 ; 1.5 ; 1.0 ; 0.0$ & & \\
\hline Initial weight (g) & 42.28 & 42.23 & 42.04 & 42.09 & 42.21 & 0.9638 & 1.57 \\
\hline Final weight (g) & 2271.29 & 2243.97 & 2243.82 & 2214.77 & 2320.72 & 0.6298 & 5.07 \\
\hline Weight gain (g) & 2229.00 & 2201.73 & 2201.78 & 2172.67 & 2278.50 & 0.6290 & 5.16 \\
\hline Feed intake (g) & 3408.30 & 3375.60 & 3543.90 & 3389.20 & 3384.00 & 0.5940 & 5.93 \\
\hline Feed conversion (g:g) & 1.533 & 1.533 & 1.610 & 1.560 & 1.486 & 0.1640 & 5.16 \\
\hline Production viability (\%) & 83.892 & 84.445 & 87.778 & 91.668 & 84.000 & 0.5352 & 10.55 \\
\hline
\end{tabular}

${ }^{1}$ Supplementation plans using a preparation containing $95 \%$ L-glutamine and $5 \%$ L-glutamic acid: $(0 ; 0)$ : no glutamine addition; $(0.5 ; 0.0)$ : addition of $0.5 \%$ glutamine from 1 to 7 days of age, followed by $0 \%$ from 8 to 42 days; $(1.0 ; 0.5 ; 0.0)$ : addition of $1.0 \%$ glutamine from 1 to 7 days of age, followed by $0.5 \%$ from 8 to 14 days and $0 \%$ from 15 to 42 days; $(1.5 ; 1.0 ; 0.5 ; 0.0)$ : addition of $1.5 \%$ glutamine from 1 to 7 days of age, followed by $1.0 \%$ from 8 to 14 days, $0.5 \%$ from 15 to 21 days, and $0 \%$ from 22 to 42 days; $(2.0 ; 1.5$; $1.0 ; 0.0$ ): addition of $2.0 \%$ glutamine from 1 to 7 days of age, followed by $1.5 \%$ from 8 to 14 days, $1.0 \%$ from 15 to 21 days, and $0 \%$ from 22 to 42 days

$\mathrm{CV}$ - coefficient of variation.

Table 5 - Carcass and cut yields in broilers fed different glutamine supplementation plans from 1 to 42 days of age

\begin{tabular}{|c|c|c|c|c|c|c|c|}
\hline \multirow{2}{*}{ Variable } & \multicolumn{5}{|c|}{ Glutamine supplementation plan ${ }^{1}(\%)$} & \multirow{2}{*}{ P-value } & \multirow{2}{*}{$\mathrm{CV}(\%)$} \\
\hline & $0 ; 0$ & $0.5 ; 0.0$ & $1.0 ; 0.5 ; 0.0$ & $1.5 ; 1.0 ; 0.5 ; 0.0$ & $2.0 ; 1.5 ; 1.0 ; 0.0$ & & \\
\hline Carcass (g) & 1637.08 & 1621.75 & 1597.08 & 1512.83 & 1616.10 & 0.0504 & 6.67 \\
\hline Breast (g) & 532.50 & 490.67 & 507.00 & 496.92 & 514.78 & 0.2468 & 9.37 \\
\hline Drumstick + thigh (g) & 500.75 & 483.75 & 467.92 & 454.25 & 484.30 & 0.1956 & 10.22 \\
\hline Wings (g) & 187.92 & 187.83 & 184.33 & 177.92 & 192.60 & 0.9900 & 9.86 \\
\hline Back (g) & 299.42 & 303.83 & 302.67 & 276.25 & 309.50 & 0.1153 & 10.53 \\
\hline Head + neck (g) & 118.67 & 124.08 & 116.92 & 115.17 & 120.60 & 0.6595 & 12.82 \\
\hline Feet $(\mathrm{g})$ & 94.50 & 102.83 & 96.83 & 89.36 & 96.90 & 0.2788 & 14.97 \\
\hline Carcass $(\%)$ & 71.85 & 71.44 & 71.20 & 69.15 & 70.62 & 0.1754 & 3.99 \\
\hline Breast (\%) & 32.53 & 30.29 & 31.82 & 32.80 & 31.82 & 0.0840 & 7.16 \\
\hline Drumstick + thigh (\%) & 30.52 & 29.81 & 29.26 & 30.10 & 29.97 & 0.7147 & 7.34 \\
\hline Wings (\%) & 11.48 & 11.58 & 11.56 & 11.53 & 11.91 & 0.8449 & 8.15 \\
\hline Back $(\%)$ & 18.33 & 18.75 & 18.97 & 18.24 & 19.13 & 0.6168 & 8.62 \\
\hline Head + neck $(\%)$ & 7.26 & 7.65 & 7.32 & 7.64 & 7.50 & 0.8062 & 12.94 \\
\hline Feet $(\%)$ & 5.75 & 6.33 & 6.05 & 5.87 & 6.00 & 0.3758 & 12.20 \\
\hline
\end{tabular}

${ }^{1}$ Supplementation plans using a preparation containing 95\% L-glutamine and 5\% L-glutamic acid: (no glutamine addition; $(0.5 ; 0.0$ ): addition of $0.5 \%$ glutamine from 1 to 7 days of age, followed by $0 \%$ from 8 to 42 days; $(1.0 ; 0.5 ; 0.0)$ : addition of $1.0 \%$ glutamine from 1 to 7 days of age, followed by $0.5 \%$ from 8 to 14 days and $0 \%$ from 15 to 42 days; $(1.5 ; 1.0 ; 0.5 ; 0.0)$ : addition of $1.5 \%$ glutamine from 1 to 7 days of age, followed by $1.0 \%$ from 8 to 14 days, $0.5 \%$ from 15 to 21 days, and $0 \%$ from 22 to 42 days; $(2.0 ; 1.5 ; 1.0$; 0.0 ): addition of $2.0 \%$ glutamine from 1 to 7 days of age, followed by $1.5 \%$ from 8 to 14 days, $1.0 \%$ from 15 to 21 days, and $0 \%$ from 22 to 42 days.

$\mathrm{CV}$ - coefficient of variation. 
no effects of supplementation on any of the carcass characteristics evaluated in broilers slaughtered at 43 days of age, which were fed diets supplemented with $0.5,0.75$, and $1.0 \%$ glutamine from 1 to 28 days of age.

Investigating broilers subjected to heat stress, Dai et al. (2011) found that supplementation with $0.5 \%$ glutamine increased carcass, breast muscle, and thigh muscle absolute weights. In a separate study by Dai et al. (2009), however, supplementation with 0.5 or $1.0 \%$ glutamine had no influence on breast absolute or relative weight at 42 days of age in broilers subjected to heat stress. In the present study, the absence if glutamine effects on carcass and cut yields possibly results from similarities in performance obtained across treatments.

\section{Conclusions}

Glutamine supplementation plans up to 21 days do not improve the performance of broilers in the periods from 1 to 21 and from 1 to 42 days of age reared in a high-temperature environment. Carcass yields and cuts of broilers at 42 days of age are not changed by glutamine supplementation for up to 21 days.

\section{Acknowledgments}

The authors thank the Universidade Federal de Mato Grasso do Sul, for providing the study material and location of experiment, and the FUNDECT for the financial resource.

\section{References}

Avellaneda, Y. A.; Quintero, J. M. H; Nieto, C. A. and Tellez, G. A. 2008. Efecto de la suplementación del glutamina y L-glutamato

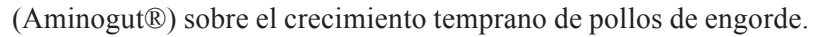
Revista de Medicina Veterinária e Zootecnia 55:77-90.

Dai, S. F.; Wang, L. K.; Wen, A. Y.; Wang, L. X. and Jin, G. M. 2009. Dietary glutamine supplementation improves growth performance, meat quality and colour stability of broilers under heat stress. British Poultry Science 50:333-340.

Dai, S. F.; Gao, F.; Zhang, W. H.; Song, S. X.; Xu, X. L. and Zhou, G. H. 2011. Effects of dietary glutamine and gamma-aminobutyric acid on performance, carcass characteristics and serum parameters in broilers under circular heat stress. Animal Feed Science and Technology 168:51-60.

Hubbard Classic. Performance summary - Broiler. 2013. Available at: $<$ http://www.hubbardbreeders.com.htm> Accessed on: Feb. 1, 2016.

Macari, M.; Furlan, R. L. and Gonzales, E. 2002. Applied physiology the broiler. 2nd ed. Funep/Unesp, Jaboticabal.

Maiorka, A.; Silva, A. V. F.; Santim, E.; Borges, S. A.; Boleli, I. C. and Macari, M. 2000. Influência da suplementação de glutamina sobre o desempenho e o desenvolvimento de vilos e criptas do intestino delgado de frangos. Arquivo Brasileiro de Medicina Veterinária e Zootecnia 52:487-490.

Martinez, K. L. A.; Leandro, N. S. M.; Café, M. B.; Stringhini, J. H.; Araújo, I. C. S. and Andrade, M. A. 2012. Suplementação de glutamina em dietas elaboradas com ingredientes de origem vegetal e animal para pintos de corte. Arquivo Brasileiro de Medicina Veterinária e Zootecnia 64:1707-1716.

Medeiros, C. M.; Baêta, F. C.; Oliveira, R. F. M.; Tinôco, I. F. L.; Albino, L. F. T. and Cecon, P. R. 2005. Efeitos da temperatura, umidade relativa e velocidade do ar em frangos de corte. Engenharia na Agricultura 13:277-286.

Murakami, A. E.; Sakamoto, M. I.; Natali, M. R. M.; Souza, L. M. G. and Franco, J. R. G. 2007. Supplementation of glutamine and vitamin $\mathrm{E}$ on the morphometry of the intestinal mucosa in broiler chickens. Poultry Science 86:488-495.

Mussini, F. J.; Goodgame, S. D.; Lu, C.; Bradley, C. D.; Fiscus, S. M. and Waldroup, P. W. 2012. A nutritional approach to the use of anticoccidial vaccines in broilers: glutamine utilization in critical stages of immunity acquisition. International Journal of Poultry Science 11:243-246.

Newsholme, P. 2001. Why is L-glutamine metabolism important to cells of the immune system in health, post-injury, surgery or infection? Journal of Nutrition 131:2515-2522.

Oliveira, R. F. M.; Donzele, J. L.; Abreu, M. L. T.; Ferreira, R. A.; Vaz, R. G. M. V. and Cella, P. S. 2006. Efeitos da temperatura e da umidade relativa sobre o desempenho e o rendimento de cortes nobres de frangos de corte de 1 a 49 dias de idade. Revista Brasileira de Zootecnia 35:797-803.

Rostagno, H. S.; Albino, L. F. T.; Donzele, J. L.; Gomes, P. C.; Oliveira, R. F.; Lopes, D. C.; Ferreira, A. S.; Barreto, S. L. T. and Euclides, R. F. 2011. Brazilian tables for poultry and swine: food composition and nutritional requirements. 3rd ed. UFV/DZO, Viçosa, MG, Brazil.

Sakamoto, M. I.; Faria, D. E.; Nakagi, V. S.; Negrão, J. A.; Araújo, R. B.; Souza, K. M. R. and Previero, T. C. 2011. Utilização da glutamina, associada ao ácido glutâmico, sobre o desenvolvimento e a atividade enzimática em frangos de corte. Arquivo Brasileiro de Medicina Veterinária e Zootecnia 63:962-972.

Siegel, H. S. 1995. Stress, strains and resistance. British Poultry Science 36:3-22.

Zavarize, K. C.; Sartori, J. R.; Pelicia, V. C.; Pezzato, A. C.; Araujo, P. C.; Stradiotti, A. C. and Madeira, L. A. 2011. Glutamine and nucleotide supplementation in broiler diets in alternative breeding system. Archivos de Zootecnia 60:913-920. 